\title{
Searching for Armed Non-state Actors' Role in the Process of Formation of Customary Law
}

\author{
Agata Kleczkowska ${ }^{1}$ \\ Polish Academy of Sciences, Institute of Law Studies, Poland \\ agata.kleczkowska@inp.pan.pl
}

KLECZKOWSKA, Agata. Searching for Armed Non-state Actors' Role in the Process of Formation of Customary Law. International and Comparative Law Review, 2019, vol. 19, no. 2, pp. 97-115. DOI: 10.2478/iclr-2019-0016.

\begin{abstract}
Summary: The paper explores the problem of the formation of the '(quasi-) customary law', as a source of law created by, or contributed to by armed non-state actors (ANSAs). It argues that, despite some views presented in the doctrine of international law, claims of a quasi-customary international law are without foundation in the current state of international law. The paper is divided into three parts. The first part presents the views of legal doctrine concerning the customary law as contributed/created by non-state actors. The second section argues that ANSAs do not form practice and opinio juris which would allow them to create their 'own' customary law. The final part presents the possible challenges and consequences of including ANSAs in the process of formation of customary international law as created by States. In summary the conclusions posit that it could be potentially very harmful for international humanitarian law and the protection of human rights.
\end{abstract}

Keywords: armed non-state actors, customary international law, quasi-custom, practice, opinio juris

\section{Introduction}

The exact number of all active armed non-state actors (ANSAs) ${ }^{2}$ all over world cannot be precisely estimated; one can only rely on indirect and approximate data, especially those related to the number of conflicts. Thus, according to the Uppsala Conflict Data Program, in 2017, there were forty-nine state-based conflicts, eighty-two non-state conflicts, and thirty-three actors engaged in onesided conflicts. ${ }^{3}$ The Program also estimates that there were around 200 armed

1 The research for this article was supported by a grant from the National Science Centre (Poland) awarded for the research project 'Liability for crimes committed by armed nonstate actors - domestic and international perspective' (UMO-2016/23/N/HS5/02849).

2 Whenever this paper uses the term 'armed non-state actors', it refers to entities which possess a certain level of organization, are composed of members who participate in the group for whatever reasons, are independent from States, and have as one of their goals the conduct of armed fight.

3 Uppsala Conflict Data Program, 'Number of Conflicts 1975-2017'. Available at: <http:// ucdp.uu.se/\#/> Accessed 15 June 2019. Idem, 'Year 2017'. Available at: <http://ucdp. 
groups engaged in different conflicts between 1989 and 2017. ${ }^{4}$ The Institute for Economics and Peace claims that in 2015 there were 148 'episodes of war, armed conflict or organized violence', and non-state armed conflicts and instances of one-sided violence were the most frequent among these episodes. ${ }^{5}$ The Geneva Call claims that since it was created in 2000, it is "engaged in dialogue" with over hundred ANSAs. ${ }^{6}$ However, these numbers give only a partial picture of the activities of all ANSAs, since one has to realize that behind these numbers there are also numerous documents issued by ANSAs. Thus, one may posit that all ANSAs together constitute a significant and influential group.

The paper explores the problem of the formation of the so-called '(quasi-) customary law', as a source of law created by, or contributed to by ANSAs. The paper assumes that ANSAs are not subjects of international law; as a result, they do not possess any rights or obligations under international law. Neither are they bound by treaty norms, because they cannot be parties to treaties; nor do they have rights and obligations under customary international law (CIL), which is created by States. Thus, claims concerning 'quasi-custom' attempt to include them into the international legal framework by creating a subtype or a separate type of customary law, which could include their vast practice and bind them. The paper argues that, despite some views presented in the doctrine of international law, claims of a quasi-customary international law are without foundation in the current state of international law, although the role ANSAs play in the international environment may constitute a starting point for the debate on how to shape and reform international law so it could be more inclusive with respect to the new developments and challenges it faces today. ${ }^{7}$

The paper is divided into three parts. The first part presents the views of legal doctrine on customary law as contributed by, or created by, non-state actors. The second section argues that ANSAs do not form practice and opinio juris which would allow them to create their 'own' customary law. The final part presents

uu.se/\#/year/2017> Accessed 15 June 2019. A non-state conflict is defined by the Program as 'the use of armed force between two organised armed groups, neither of which is the government of a state, which results in at least 25 battle-related deaths in a year' (statebased is the opposite); and 'one-sided violence' refers to 'the use of armed force by the government of a state or by a formally organised group against civilians which results in at least 25 deaths in a year.

4 See Pettersson, Therese, Eck, Kristine. Organized violence, 1989-2017. Journal of Peace Research, 2018, vol. 55, no. 4, pp. 535-547.

5 Institute for Economics and Peace, 'Global Peace Index 2017', pp. 48-49. Available at: $<$ http://visionofhumanity.org/app/uploads/2017/06/GPI17-Report.pdf > Accessed 15 June 2019.

6 Geneva Call, 'Mission'. Available at: <https://genevacall.org/who-we-are/> Accessed 15 June 2019.

7 In support of this thesis see e.g. International Law Commission, 'Fourth report on identification of customary international law, by Sir Michael Wood, Special Rapporteur' (2 May10 June and 4 July-12 August 2016) A/CN.4/695, par. 21. 
the possible challenges and consequences of including ANSAs in the process of formation of CIL as created by States. The conclusions posit that it could be potentially very harmful for international humanitarian law (IHL) and the protection of human rights.

\section{The concept of quasi-customary law in the doctrine of law}

Since few authors support the concept of "quasi-custom" in different forms, it is worth to briefly discuss their views on this idea.

Firstly, Anthea Roberts and Sandesh Sivakumaran claim that ANSAs may participate in the creation of what they call "quasi custom,"8 a concept which includes the practice of both States and ANSAs. These Authors present three conditions of the creation of such 'quasi-customary law', that is: ANSAs should be bound by existing CIL to preserve the stability of protection provided by international law; a new custom could be created only under the cooperation of States and ANSAs, so that the ANSAs "could contribute to the process of developing customary law, without being able to control its outcome"; practice of States and ANSAs would not be treated equally but the practice of States would be given more weight. ${ }^{9}$ However, the Authors do not elaborate more on this idea, neither clarify whether this "quasi custom" would constitute a separate source of law towards the CIL created only by practice and opinio juris of States; whether it would replace the traditional CIL etc.

Secondly, Raphaël van Steenberghe notes that ANSAs should be bound by norms of IHL on the grounds of CIL, but not that created by States' practice and opinio juris, but rather "customary law created by armed groups themselves and only applicable to those groups, like custom created by international organizations and applicable to those organizations." ${ }^{10}$ In the meantime, van Steenberghe opposes giving ANSAs a custom - making capacity. ${ }^{11}$

8 Roberts, Anthea, Sivakumaran, Sandesh. Lawmaking by Nonstate Actors: Engaging Armed Groups in the Creation of International Humanitarian Law. Yale Journal of International Law, 2012, no. 37 (1), pp. 149-150. It should be noted that different authors use the term 'quasi-custom' for different purposes. See e.g. Liang, Jessica. Modifying the UN Charter through Subsequent Practice: Prospects for the Charter's Revitalisation. Nordic Journal of International Law, 2012, no. 81 (1), pp. 5-6 ft 200 or Chafin, Haley Elizabeth. Stolen Innocence: The United Nations' Battle against the Forced Recruitment and Use of Child Soldiers in Myanmar. Georgia Journal of International and Comparative Law, 2014, no. 43 (1), p. 195. M. Bos by 'quasi-custom' understands "rules of general application, not supported by any practice or opinio juris" (Bos, Marteen. The Identification of Custom in International Law. German Yearbook of International Law, 1982, no. 25, p. 50).

9 Roberts and Sivakumaran (note 7) 151.

10 van Steenberghe, Raphaël. Non-state actors from the perspective of the International Committee of the Red Cross. In d'Aspremont Jean (ed). Participants in the International Legal System. Multiple perspective on non-state actors in international law. Abingdon: Routledge, 2013, p. 222.

11 Ibidem. 
Thirdly, Marco Sassòli also refers to IHL, but suggests creating a new category of armed conflict, i.e. between States and terrorist organizations, and then creating a new body of law which would regulate only such conflicts. ${ }^{12}$

Fourthly, the group 'Governance. Social Development. Humanitarian. Conflict. Applied Knowledge Services' - in its report entitled 'International Legal Frameworks for Humanitarian Action' - claims that quasi-custom is a way for allowing ANSAs to play a role in the creation of customary IHL; this claim can be realized by the "publishing of their codes of conduct, internal orders, drafted constitutions and penal codes, many of which may contain IHL provisions." ${ }^{13}$

Fifthly, Hugh Thirlway referring to the notion of 'quasi-custom', postulates that the idea could be used to bolster the participation of non-state actors in international life "in a more direct way". ${ }^{14}$ However, he does not insist on the creation of such 'quasi-custom', but rather mentions "some kind of law-making activity" as a way of increasing non-state actors' participation in international relations "not fitting into the traditional categories." ${ }^{15}$

Finally, it is worth to mention that Anthony Clark Arend asserts that CIL could contain rules of different types, including rules which would be binding "on all types of international actors", adding that the mutual interactions of these actors would contribute to the formation of these rules. On the other hand, he also claims that there could be rules binding only on "some, not all, international actors." ${ }^{16}$

Summing up these views, it should be observed that there is neither a consistent idea of what this quasi-custom would be composed of, nor of exactly what the role of ANSAs would be in its creation. The viewpoints mentioned above leave many doubts as to whether this 'customary law of ANSAs' would be a body of law separate from the CIL formed by States; what would be the consequences of binding ANSAs with CIL; and whether they have law-making capacity. However, it seems that a prerequisite to answering all these questions is to examine the practice and opinio juris of ANSAs in order to find out how the conduct of different ANSAs could interact, and how it could be related to the traditional process of formation of CIL.

12 Sassòli, Marco. Transnational Armed Groups and International Humanitarian Law. Program on Humanitarian Policy and Conflict Research Harvard University Occasional Paper Series, 2006, no. 6, p. 25.

13 Governance. Social Development. Humanitarian. Conflict. Applied Knowledge Services, 'International Legal Frameworks for Humanitarian Action. Topic Guide', p. 45. Available at: $\quad<$ https://reliefweb.int/sites/reliefweb.int/files/resources/International\%20Legal\%20 Frameworks\%20for\%20Humanitarian\%20Action.pdf> Accessed 15 June 2019.

14 Thirlway, Hugh. The Sources of International Law. Oxford: Oxford University Press, 2014, p. 18.

15 Ibidem.

16 Arend, Anthony Clark. Legal Rules and International Society. Oxford: Oxford University Press, 1999, pp. 177-178. 


\section{Process of formation of CIL and ANSAs}

\subsection{General remarks}

Today, the most common approach to CIL is the so called 'two-element' approach, which assumes that the identification of a CIL norm requires an assessment of both practice (usus) and the acceptance of that practice as law (opinio juris). ${ }^{17}$ Insofar as a detailed examination of the elements of customary norms would require a separate dissertation, it is sufficient here to distinguish the most relevant traits of both practice and opinio juris as they relate to the topic of this article.

Insofar as practice is concerned, firstly it has to be attributable to a State. Thus, the acts of all branches of government, as well of all entities and individuals which may be attributed to a State are relevant for the process of formation of CIL. ${ }^{18}$ Secondly, States' practice is composed of both physical and verbal acts; and a State's inaction may also be relevant. ${ }^{19}$ According to the ILC, among examples of the manifestations of practice one can enumerate: physical actions of States; diplomatic acts and correspondence; conduct in connection with resolutions adopted by an international organization or at an intergovernmental conference; conduct in connection with treaties; acts of the executive, legislative and administrative branches; decisions of national courts; internal memoranda by States' officials; and official publications in the field of international law. ${ }^{20}$ Thirdly, while a practice does not have to be universal it should nevertheless be sufficiently widespread. ${ }^{21}$ Fourthly, the practice should be consistent; thus when a practice is uncertain or contradictory, there is no uniform usus. ${ }^{22}$ However,

17 International Law Commission, 'Second report on identification of customary international law by Michael Wood, Special Rapporteur' (5 May-6 June and 7 July-8 August 2014) A/CN.4/672, par. 21; Postema, Gerald J. Custom in international law: a normative practice account. In Perreau - Saussine, Amanda, Murphy, James Bernard (eds) The nature of customary law: Legal, historical and philosophical perspectives. Cambridge: Cambridge University Press, 2007, p. 280; Thirlway (note 13) 56-57; Cassese, Antonio. International Law. Oxford: Oxford University Press, 2005, p. 158; Crawford, James. Brownlie's Principles of Public International Law. Oxford: Oxford University Press, 2012, p. 23; Kopelmanas, Lazare. Custom as a Means of the Creation of International Law. British Year Book of International Law, 1937, no. 18, p. 135; Oeter, Stefan. The Legitimacy of Customary International Law. In Eger, Thomas, Oeter, Stefan, Voigt, Stefan (eds). Economic Analysis of International Law. Contributions to the XIIIth Travemünde Symposium on the Economic Analysis of Law (March 29-31, 2012). Tübingen: Mohr Siebeck, 2014, p. 16.

18 ILC (note 16) par. 34; Wolfke, Karol. Custom in present international law. Dordrecht: Springer, 1993, p. xvii; Mendelson, Maurice. The Formation of Customary International Law. Recueil de Cours, 1998, vol. 272, p. 198.

19 ILC, 'Text of the draft conclusions provisionally adopted by the Drafting Committee' (2 May-10 June and 4 July-12 August 2016) A/CN.4/L.872, Conclusion 6[7], par. 1.

20 Ibidem, Draft conclusion 6 [7] par. 2.

21 ILC (note 16) par. 52.

22 Ibidem, par. 55, 57. 
this does not mean that complete consistency is required. ${ }^{23}$ Fifthly, even though CIL "traditionally emerged as a result of a practice extending over a lengthy period of time," shorter practices, or even precedents, may be relevant as well. ${ }^{24}$

When it comes to opinio juris, first and foremost it has to be distinguished from other extra-legal considerations, such as courtesy, political expediency or tradition..$^{25}$ Thus, opinio juris means that States specifically regard a certain practice as having the force of law. Among the examples of opinio juris, one may enumerate public statements made on behalf of States; official publications; opinions presented by governments' legal advisors; internal memoranda by State officials; diplomatic correspondence; decisions of national courts; treaties and their travaux preparatoires; and conduct in connection with resolutions adopted by an international organization or at an intergovernmental conference. ${ }^{26}$

Given the above, it should be highlighted that it is sometimes very difficult to distinguish those acts of States which may be qualified as manifestations of practice from those which may serve as opinio juris. ${ }^{27}$ For example, it is hard to determine in general whether verbal statements of States are examples of practice or opinio juris; the qualification of such actions is possible only by examining the specific circumstances of each and every instance. ${ }^{28}$ However, even when sharp distinction between manifestations of practice and opinio juris is not possible, it should not disqualify these manifestations from being taken into account in the process of formation of CIL.

\subsection{ANSAs and formation of CIL}

\subsubsection{Manifestations of ANSAs' practice}

First and foremost, it should be observed that, as in case of States, so too there are many examples of conduct by ANSAs. Among them are unilateral declarations, codes of conduct, statements of leaders, agreements concluded between ANSAs, States, international organizations and non-governmental bodies, deeds of commitment, internal rules and regulations, declarations of compliance, correspondence, as well as factual acts, omissions, and inaction. Thus, there is plethora of acts to analyse in order to examine their meaning and the convergences between them.

23 Military and Paramilitary Activities in und against Nicaragua (Nicaragua v. United States of America), Merits (Judgment), 27 June 1986 [1986] ICJ Rep 14, par. 186.

24 ILC (note 16) par. 58.

25 Ibidem, par. 61.

26 ILC (note 18) Draft conclusion 10 [11], par. 2.

27 Arajärvi, Noora. The Changing Nature of Customary International Law: Methods of interpretation the concept of custom in international criminal tribunals. Abingdon: Routledge, 2014, p. 27.

28 Mendelson (note 17) 206. 
Analysing these manifestations of conduct from the standpoint of their relevance for the process of formation of CIL, the first conclusion which can be drawn is that the acts of ANSAs vary considerably between themselves, especially with respect to their underlying intent. Thus on one hand, in looking for ANSAs' acts which potentially could be included in the process of creation of custom one should take into account acts which refer to possible obligations of ANSAs under international law, legal instruments or institutions. An example may be the Declaration and Program of Action for the Rights, Protection and Welfare of Children issued by the National Democratic Front of the Philippines (NDFP), which

reaffirms the rights of children and resolves to carry out a program of action for the protection and welfare of children within the framework of the Guide for Establishing the People's Democratic Government (1972), or the 1996 NDFP Unilateral Declaration of Undertaking to Apply the Geneva Conventions of 1949 and Protocol I of 1977. ${ }^{29}$

On the other hand, some of the declarations and agreements issued by ANSAs include explicit statements testifying to their political character. For instance, the 'Agreement on Human Rights' established between the Government of El Salvador and the Frente Farabundo Martí para la Liberación Nacional (FMLN) states in its preamble: "On the understanding that for the purposes of the present political agreement (...)," which clearly demonstrates the political will of the parties to the instrument. ${ }^{30}$ Thus, if the will underlying the idea of this agreement was not to create legal obligations, it should not be taken into account in the process of formation of any legal norms, including CIL.

However, sometimes it is hard to determine the status of some acts of ANSAs. One can refer here to, e.g., the letter from the Algerian National Liberation Front to the Committee of the Red Cross. ${ }^{31}$ In this correspondence, the delegation of the Front indicated that since the beginning of the conflict with France, the French side had been violating the III Geneva Convention relative to the Treatment of Prisoners of War. The Front itself declared that it was "ready to apply" the provisions of this Convention in relation to all French soldiers captured by the Front on the grounds of Art. 2 (3) of the Convention, under the condition however of reciprocity of the application of the Convention by the French side. Consequently, the consent to be bound by the III Geneva Convention was con-

29 Available at: <http://theirwords.org/media/transfer/doc/1_ph_ndfp_2012_4695b83d5994c9d675fa79541522e8c177.pdf> Accessed 15 June 2019

30 United States Institute of Peace, 'Agreement on human rights'. Available at: <https://www. usip.org/sites/default/files/file/resources/collections/peace_agreements/pa_es_07261990_ hr.pdf> Accessed 15 June 2019.

31 Algerian National Liberation Front, 'Lettre du Comité de Libération de l'Afrique du Nord au Comité International de la Croix-Rouge. Available at: <http://theirwords.org/ media/transfer/doc/sc_dz_fln_aln_1956_03-ad93ce79b5a926e49501e3d304a82b73.pdf > Accessed 15 June 2019. 
ditional, and since the authors of the letter were aware that it was highly doubtful that the declaration would really influence the conduct on the part of France, the issuance of the letter must be seen as nothing more than a political act.

Another problem arises when ANSAs are issuing some acts while aware that they cannot be binding on them under international law. In support of this argument, one can refer to the resolution issued by the Sudan People Liberation Movement/Army - North (SPLM/A-N), which established an independent Human Rights Court "to address complaints of human rights violations in SPLM/A-N's liberated areas." ${ }^{32}$ Thus, even though the jurisdiction of the Court was focused on violations of human rights, i.e. international legal norms, the SPLM/A-N did not refer the cases of these violations to any international organ but decided to punish the perpetrators of such violations on its own, creating a separate judicial regime for that purpose. This means that the SPLM/A-N considers itself bound by human rights, but not under international law.

Summing up, in the absence of an explicit declaration it is hard to assess which statements made by ANSAs could potentially be relevant for the formation of custom or quasi-custom.

\subsubsection{Consistency of practice}

\subsubsection{Internal consistency of practices of ANSAs}

As described above, in the process of formation of CIL a practice should be generally consistent, and contradictions and uncertainties exclude the uniformity of usus and thus undermine the process of formation of customary norms. Hence, one needs to examine whether the practice of ANSAs is sufficiently consistent that it could form or contribute to the formation of customary norms.

However, before the practices of different ANSAs are compared from the standpoint of their consistency, one needs to examine whether the ANSAs practice is consistent internally, i.e. whether ANSAs follow their own declarations and are consequent in their actions. In this regard, four different attitudes may be distinguished.

Firstly, one should observe that the declarations of ANSAs with regard to the observance of human rights and IHL are usually very general in nature and do not refer to any particular legal instruments. Probably the most general regulation was issued by the Revolutionary United Front of Sierra Leone, entitled 'The Eight Codes of Conduct', which included literally eight laconic rules:

To speak politely to masses; To pay fairly for all [that] you buy; To return everything that you borrow; To pay for everything that you demand or

32 SPLM/A-N, 'Resolution No. (6)-2013', Available at: <http://theirwords.org/media/transfer/doc/splm_n_human_rights_court_en_1-c19ad16282af42e9765a1ce3569950bd.pdf> Accessed 15 June 2019. 
damage; Do not damage crops; Do not take liberty from women; Do not ill-treat captives; Do not hate or swear at people. ${ }^{33}$

It would be hard to assess the legal meaning of these "Eight Codes", especially in terms of observance of international law, or to verify how the Front itself follows these rules.

Secondly, it also happens that ANSAs' declarations or agreements are very specific and include very narrow commitments or refer only to some specific situation. Consequently, one may infer that an ANSA does not feel obliged to observe the whole range of human rights and IHL norms, but only these limited rules they declare their acceptance of. For instance, in 1992 the Mozambique National Resistance (RENAMO) issued a Joint Declaration with the Government of Mozambique on the Guiding Principles of Humanitarian Assistance, in which it declared, inter alia, that "Assistance shall go to all affected Mozambicans, freely and without discrimination" (par. I (a)). ${ }^{34}$ However, this did not mean that RENAMO ceased human rights or IHL violations in general. As pointed out by Amnesty International (AI) in its 2016/2017 report, only recently RENAMO members and supporters looted health facilities, as well as carried out attacks on highways and police stations, causing a number of casualties among the general population. ${ }^{35}$ Thus, this singular agreement could not be treated as a general declaration made by the RENAMO about the observance of human rights or IHL norms. Similar examples can be found in the practice of other ANSAs.

Thirdly, apart from taking advantage of the narrow commitments they make, ANSAs also often violate their own declarations. This is true both with regard to agreements concluded by the ANSAs on their own, as well as to declarations or agreements made under the auspices of some international bodies. When it comes to the former instance, one can refer to the example of the Sudan People Liberation Army (SPLA), which in March 2002 concluded an agreement with the Government of the Republic of Sudan "to Protect Non-Combatant Civilians and Civilian Facilities from Military Attack," ${ }^{36}$ whereby the parties agreed, inter alia, to refrain from targeting or intentionally attacking non-combatant civilians, or facilities such as schools, hospitals, religious premises, health and food distribution centres (par. 1 (a) (b)). However, after the agreement was concluded, international bodies many times reported serious human rights violations perpetrated by the SPLA on civilians. The UN Office of the High Commissioner for Human Rights' report from March 2016 gives numerous examples of the killings

33 Available at: <http://theirwords.org/media/transfer/doc/sl_ruf_01-1678c63ea48fb4e15f0f50c7c53ef15b.pdf> Accessed 15 June 2019.

34 Available at: <http://theirwords.org/media/transfer/doc/mz_renamo_1992734e52603d5bdd69f4761aad9247ecad.pdf> Accessed 15 June 2019.

35 AI, Amnesty International Report 2016/17: The State of the World's Human Rights, London: AI, 2017, p. 262.

36 Available at: <http://theirwords.org/media/transfer/doc/sd_splm_a_2002_09-aca3835caf6b2926ed2df65b66ae9acb.pdf> Accessed 15 June 2019. 
of civilian populations by this group, enumerating, inter alia, that in the period from December 2013 to December 2015 the SPLA "killed civilians, including women, children and older persons, raped women and girls, looted and burnt civilian property and pillaged tens of thousands of livestock." ${ }^{37}$ One can also mention the "Report on Violations and Abuses of International Human Rights Law and Violations of International Humanitarian Law in the context of the fighting in Juba, South Sudan," issued by the UN Human Rights Office, which is limited only to the period between 8 and 12 July 2016 in Juba. According to the report, even in this short time the SPLA soldiers reportedly shot directly at or indiscriminately in very close proximity to United Nations Mission in South Sudan's Protection of Civilians sites, killing fifty-three people, while at least 234 were reported injured (par. 39-40).

When it comes to declarations submitted under the auspices of international bodies, one can refer to the example of the Deed of Commitment for the protection of children from the effects of armed conflict, created under the auspices of the Geneva Call, which was signed by, inter alia, SPLM/A-N. However, in its recent report on situation of children in armed conflicts the UN SecretaryGeneral pointed out that in 2017 the United Nations received allegations of recruitment and use of boys by the SPLM/A-N in Kurmuk, Blue Nile, although no cases could be verified. ${ }^{38}$ Likewise, a Syrian armed group, the People's Protection Units, signed the Deed in 2014, but according to the UN Secretary-General's report, it was listed as a party that "have not put in place measures during the reporting period to improve the protection of children."39

Fourthly, it should be acknowledged that a number of ANSAs have complied with declarations they issued. A recent well-known example of that concerns the Revolutionary Armed Forces of Colombia (FARC), which in 2016 signed a bilateral ceasefire and cessation of hostilities agreement with the government of Colombia. According to the AI, since that time the number of cases of human rights abuses attributable to the FARC has fallen, and in addition FARC formally apologized for its role in human rights violations. ${ }^{40}$ Moreover, recently the media reported that it is the Colombian government which primarily fails to comply with the peace accord, and that FARC is putting pressure on the government to continue to observe the agreements. ${ }^{41}$

37 United Nations High Commissioner for Human Rights, 'Report of the United Nations High Commissioner for Human Rights', 10 March 2016, A/HRC/31/49, par. 14.

38 'Report of the Secretary-General: Children and Armed Conflict', 16 May 2018, A/72/865S/2018/465, par. 175.

39 Ibidem, p. 40.

40 AI (note 34) 125-126.

41 'Letter to President by Rodrigo Londoño Echeverri'. Available at: <http://www.farc-ep.co/ comunicado/que-se-cumpla-lo-prometido-y-firmado-presidente-santos.html $>$ Accessed 15 June 2019. 
In summarizing these events and data, it may be said that even though ANSAs select on their own the rules they wish to observe, and narrow as much as possible the extent of the commitments they make, they still often fail to observe their own declarations. Obviously, that is also often the case with States, which are obliged to follow certain legal obligations and breach them in the end. However, there are two substantial differences between the conduct of States and ANSAs when it comes to breaches of humanitarian law and human rights norms. First of all, even if States breach these norms, they still declare their compliance with international law and endeavour to justify their actions as legal, while ANSAs do not look for any justifications for their breaches. Secondly, ANSAs select and voluntarily declare their compliance only with a very limited number of legal norms, which not only puts them in a very privileged position but virtually also means that they do so because they are ready and willing to follow these obligations. If they fail to comply with even these narrow declarations, this means that they treat them only as political or moral acts and do not feel bound by any legal obligations. Moreover, contrary to the States' practice, it would be difficult to apply the rule formed by the ILC, that " $[\mathrm{w}]$ here the practice of a particular State varies, the weight to be given to that practice may be reduced", 42 since in case of the ANSAs majority of their practice would have to be omitted.

\subsubsection{Comparing the practices of different ANSAs}

One needs to note that since ANSAs' declarations and agreements substantially vary among themselves, it is hard to observe any consistency between them. Even more, it does not seem that these declarations follow one pattern or are focused, at least in majority, on some specific field. Having said that, projects like the Geneva Call's Deeds of Commitment undoubtedly may play a great role in harmonizing the commitments made by ANSAs. Currently, the Deeds concern four fields: total ban on anti-personnel mines and for cooperation in mine action; protection of children from the effects of armed conflict; prohibition of sexual violence in situations of armed conflict and towards the elimination of gender discrimination; protection of health care in armed conflict. ${ }^{43}$ The Deeds have fixed texts which cannot be changed by the ANSAs, thus all armed groups make exactly the same commitments. While the Deeds do not refer to any particular treaty or customary obligations claiming that they are binding on ANSAs, ${ }^{44}$ they still may be treated as a clear declaration on the part of ANSAs

42 ILC (note 18) Draft conclusion 7 [8], par. 2.

43 The texts of the three former Deeds are available on the Geneva Call website: https://genevacall.org/how-we-work/deed-of-commitment/. The last Deed, on the protection of health care in armed conflicts was launched only in November 2018 and the Geneva Call has not announced its text yet (https://genevacall.org/geneva-call-launches-an-innovative-newdeed-of-commitment-on-protecting-health-care-in-armed-conflict/).

44 However, it is noteworthy to observe that the Deeds contain a clause by which the ANSAs assert that "This Deed of Commitment shall not affect our legal status, pursuant to the relevant clause in common article 3 of the Geneva Conventions of August 12, 1949". 
that they are willing to refrain from violating at least these obligations. However, even though the majority of ANSAs which have signed the Deeds are not mentioned afterwards in the reports prepared by international bodies on the violations of humanitarian or human rights norms, twenty-four ANSAs have signed the Deed concerning the mines, twenty-six - on the protection of children, and twenty three have signed the Deed on the prohibition of sexual violence ${ }^{45}$. Given the numbers highlighted in the introduction to this paper, this means that only a small percentage of ANSAs have decided to adhere to the Deeds.

To put it differently, if there is any consistency in practice of different ANSAs, it is only in the sense that it is composed of violations of IHL and human rights norms. It is impossible to invoke here all the statistics connected with violations of international law by ANSAs, but to give an idea of the scale of the problem one can mention that the Report "Accountability for Human Rights Violations and Abuses in the DRC: Achievements, Challenges and the Way forward" indicated that between 1 January 2014 and 31 March 2016, the United Nations Joint Human Rights Office documented at least 3,356 human rights abuses committed by alleged combatants of different armed groups throughout the Democratic Republic of Congo (para 8). The AI Report claims that throughout 2016 and 2017, armed groups in Mali carried out several attacks against UN forces, killing twenty-five peacekeepers and six civilian contractors working for the UN; moreover, landmines used by armed groups killed and maimed civilians, peacekeepers and members of the security forces. ${ }^{46}$ The number of human rights abuses carried out by ISIS, as well as affiliated groups, are countless; according to Human Rights Watch in Syria alone, apart from killing civilians in attacks ISIS continues to torture, rape and sexually enslave Yazidi women and children, many of whom were abducted in Iraq and taken to Syria, as well as executes men accused of homosexuality; while other groups fighting in Syria attack civilian objects like schools, mosques, and markets. ${ }^{47}$ Many other examples could be invoked, including from media coverage.

To sum up, if there is any consistency between the different acts of ANSAs, it is rather in their acts of violation of international law. The declarations made by ANSAs do not allow for drawing any conclusions on the consistency of the practice of ANSAs, since it varies too much and only a small portion of it is harmonized by the declarations such as the Deeds of Commitment.

\subsubsection{Other elements of practice}

While consistency is not the only trait of practice that counts in the process of formation of CIL, it seems that the other characteristics are consequences of the

45 Geneva Call, 'Annual Report 2017', p. 27.

46 AI (note 34) 245.

47 Human Rights Watch, 'Syria. Events of 2016. Available at: <https://www.hrw.org/worldreport/2017/country-chapters/Syria> Accessed 15 June 2019. 
consistency (or inconsistency) of a practice. Firstly, it is hard to discuss whether the ANSAs' conduct is widespread if their acts vary so much between themselves, and even a single ANSA can fail to have consistent practices. Secondly, it is likewise impossible to examine whether the ANSAs' practice is sufficiently long-lasting, since it is too different; while at the same time there are no precedents which would change this state of affairs.

\subsubsection{Opinio juris}

As has been illustrated, opinio juris means that States regard a certain practice as having the force of law. Thus, in case of ANSAs they too could theoretically regard a certain practice as law which is binding on them. It was also shown that in case of States it may be hard to distinguish between acts which constitute practice and opinio juris. The same is also true with regard to ANSAs. Thus, one may assume that some of the above-mentioned declarations and agreements made by ANSAs could also serve as expressions of opinio juris. However, to verify if they really may be treated as such, one needs to verify what the ANSAs say through their acts.

In the Deeds of Commitment ANSAs "hereby solemnly commit [themselves] to the following terms: [...]." The Free Syrian Army in its "Declaration" "emphasized" that "the areas where the revolutionary forces have besieged have been strictly militarily sieged," as well as assured "that areas within our control are safe." ${ }^{48}$ The Karen National Union/Karen National Liberation Army of Burma/Myanmar (KNU) claims that "The KNU respects and promotes the fundamental principles of humanity," as well as "Where security and safety for either ordinary citizens or humanitarian assistance providers are at risk, the KNU is duty-bound to take the appropriate protective security measures." 49 The Comprehensive Agreement on Respect for Human Rights and International Humanitarian Law, concluded between Government of the Republic of the Philippines and the NDFP, states that "[t]he Parties recognize fundamental individual and collective freedoms" (art. 4), as well as "affirm the need to promote, expand and guarantee the people's democratic rights and freedoms" (art. 5) s0 $^{50}$ According to the N'Djamena Protocol on the Establishment of Humanitarian Assistance,

The Government of the Republic of Sudan, the Sudan Liberation Movement and the Movement for Justice and Equality (...) have agreed as follows: (...) Human sufferings will be taken into account wherever they are

48 Available at: <http://theirwords.org/media/transfer/doc/fsa_declaration_20161078a35c56fc236e94abb00ac3911717.pdf> Accessed 15 June 2019.

49 KNU, 'Policy on Humanitarian Operation in Ceasefire Zone'. Available at: <http://theirwords.org/media/transfer/doc/knu_policy_on_humanitarian_operation_2013-f27bab81ffc78dc8d7b2592422b0a437.pdf> Accessed 15 June 2019.

50 Available at: $<$ http://theirwords.org/media/transfer/doc/ph_ndfp_1998_17-ef3249df335f48cd378d1c5082457be4.pdf> Accessed 15 June 2019. 
found (...); Humanitarian assistance is provided regardless of ethnic origin, gender, nationality, opinions, race or religion (...). ${ }^{51}$

Many other instances could be invoked. However, these examples, concerning different ANSAs from different parts of the world and created under different circumstances, allow for drawing some general conclusions. Firstly, in their declarations ANSAs do not claim that there is any practice which they recognize as law binding on them, neither explicitly nor implicitly. Rather, they either assert that in their practice they follow general humanitarian standards, declare that they recognize these standards, or, as in case of Deeds, ANSAs "commit" themselves to following certain rules. Secondly, these declarations do not refer to States' practice or the practice of other ANSAs, but rather to specific situations and the position the ANSAs have in the conflict in which they participate. Thirdly, none of the statements contains a declaration that an ANSA "is obliged", "feels obliged", "has an obligation" etc., but rather they are very soft and vague vows which do not resemble binding declarations made by States. Finally, none of them mentions that ANSAs could be bound by international legal norms, neither do they refer to any particular norms.

However, there are also examples where ANSAs have made declarations on specific legal obligations. For instance, in a message of 25 July 1980 addressed to the ICRC, the National Union for the Total Independence of Angola (UNITA), stated that "UNITA renews its commitment to the Geneva Conventions and subscribes to the fundamental rules of international law applicable in armed conflicts $(. .).)^{\prime 52}$

Likewise, O. R. Tambo, President of the African National Congress, issued a declaration on 28 November 1980 that the Congress

intends to respect and be guided by the general principles of international humanitarian law applicable in armed conflicts. Wherever practically possible, the African National Congress of South Africa will endeavour to respect the rules of the four Geneva Conventions of 12 August 1949 for the victims of armed conflicts and the 1977 additional Protocol I relating to the protection of victims of international armed conflicts. ${ }^{53}$

Then, in 1988, the FMLN issued a declaration wherein it stated that "The FMLN shall ensure that its combat methods comply with the provisions of common Article 3 of the Geneva Conventions and Additional Protocol II, take into

51 United States Institute for Peace, 'Humanitarian Cease Fire Agreement on the Conflict in Darfur'. Available at: <http://theirwords.org/media/transfer/doc/1_sd_slm_sla_jem_2004 _33d3bacd2ca5696d09881a15de522cf21a. pdf> Accessed 15 June 2019.

52 Declaration by UNITA. International Review of the Red Cross, November-December 1980, no. 219 , p. 320.

53 Declaration of intent by the African National Congress. International Review of the Red Cross, January-February 1980, no. 220, p. 20. 
consideration the needs of the majority of the population, and defend their fundamental freedoms." 54

Interestingly, the Palestine Liberation Organization (PLO) not only declared that it wishes to comply with IHL but also that it would like to adhere to the Four Geneva Conventions of 12 August 1949 and the two Protocols additional thereto. ${ }^{55}$

These examples show that it is possible for non-state actors to commit themselves to specific legal obligations. However, one needs to observe that the PLO was in a special position when issuing its declaration, since it was submitted after it declared Palestine's independence and at a time when it sought to be recognized as the legitimate Palestinian authority; on the other hand, the declarations of the African National Congress, UNITA, and FMLN do not claim that these actors are bound by the Geneva Conventions under international law, since they only "renew the commitment", "intend to respect" or "ensure" that they "will comply with." Thus, these four specific cases do not change the overall assessment of the expressions of opinio juris by ANSAs: while the PLO submitted its declaration not as an ANSA but as authorities of a newly declared State, the remaining three actors employed very vague language which denies that they considered their commitments as legally binding.

In summary, it is hard to deduce any consistent practice, nor any manifestations of opinio juris from the conduct of ANSAs. If there is any consistency in their practice, it is primarily because of violations of basic humanitarian standards, and even if ANSAs' acts do refer to particular legal rules, they do not seem to express any recognition of the binding force of these rules. Given that, it is impossible to ascertain the existence of any special branch of customary law formed by practice and opinio juris of ANSAs.

\section{Contribution of ANSAs to the CIL formed by States}

As has been shown above, ANSAs cannot form independent customary law. The only remaining possibility is that their acts could be included in the CIL formed by States. Thus, the pros and cons of such an approach should be analysed.

Firstly, as was demonstrated above, the acts of ANSAs consist mostly of breaches of IHL and human rights norms. Moreover, contrary to States' practices, ANSAs do not endeavour to make the international community believe that their conduct is in compliance with these norms. As a result, including the

54 Prosecutor v. Dusko Tadic A/K/A “Dule” IT-94-1 2 October 1995 (Decision on the Defence Motion for Interlocutory Appeal on Jurisdiction), par. 107.

55 Palestine and the Geneva Conventions. International Review of the Red Cross, JanuaryFebruary 1990, no. 274, p. 64. 
practice of ANSAs in the process of formation of CIL would amount to a regression in terms of the significance and protective values of these norms. ${ }^{56}$

Secondly, one of the factors that is indispensable in the process of creation of customary norms is the will and consent of States. Not only can they protest against the formation of norms of CIL, but also their objections can be taken into account due to the persistent objector institution. Consequently, if the practice of ANSAs is to be included in the process of formation of CIL, they would have to consent to the fact that their conduct can result in the formation of legally binding norms. However, there are no declarations on the part of ANSAs which would suggest that they are aware that their acts could play a role in forming customary legal norms, nor that they consent to it.

Thirdly, since it is hard to deduce any manifestations of opinio juris from the conduct of ANSAs, this means that their acts could potentially contribute to only one of the elements of customary norms, i.e. practice. Thus, one may ask whether it is possible that ANSAs contribute to only one of the elements of custom and still are bound by it on equal terms as States?

Fourthly, one needs to consider the implications of including the ANSAs' conduct in the process of formation of CIL from the standpoint of binding ANSAs with legal norms. Some authors claim that incorporating the practice of ANSAs into the formation of custom "would (...) give them a sense of ownership of the rules, potentially making them less willing to break these rules. ${ }^{\prime 57}$ However, why should they comply with norms of a legal system they do not belong to? Does this mean that if their conduct would be included in the process of formation of CIL, they would automatically be bound by CIL on the same grounds as States are bound? Would it mean that they may be held responsible for their breaches of CIL? Who would decide if a particular armed group is bound by CIL?

Many more doubts may be raised in relation to this issue. However, if these questions were the only obstacles towards binding ANSAs with CIL, probably it would be worth the risk to include their practice in the process of formation of CIL, if doing so would help increase their compliance with CIL. Unfortunately, one cannot ignore the negative contribution the ANSAs may make to CIL by their violations of IHL and human rights. As a result, taking into account the current status of ANSAs and the role they play in international relations, the contribution of their practice to the formation of CIL would be impossible from the technical standpoint of the process of formation of CIL, and potentially very harmful for the international community.

56 Ryngaert, Cedric. Non-State Actors and International Humanitarian Law. Working Paper, 2008, p. 6. Available at: <https://www.law.kuleuven.be/iir/nl/onderzoek/wp/WP146e.pdf> Accessed 15 June 2019.

57 Sivakumaran, Sandesh. Binding Armed Opposition Groups. International and Comparative Law Quarterly, 2006, vol. 55, p. 375. 
The argument that ANSAs' practice should not be included in the process of formation of CIL has also been supported by two international bodies, i.e. the ICRC and the ILC. The ICRC textbook 'Customary International Humanitarian Law' states that:

The practice of armed opposition groups, such as codes of conduct, commitments made to observe certain rules of international humanitarian law and other statements, does not constitute State practice as such. While such practice may contain evidence of the acceptance of certain rules in non-international armed conflicts, its legal significance is unclear and it has therefore been listed under "Other Practice" in Volume II. ${ }^{58}$

A quite similar approach was assumed in the draft conclusions of the ILC's works on the formation and evidence of CIL, as it claimed that the requirement of practice means first and foremost the practice of states, while the practice of international organizations may in certain situations be taken into account as well. At the same time, the conduct of other actors does not amount to "the formation, or expression, of rules of customary international law, but may be relevant when assessing the practice of states and international organizations." ${ }^{9}$

\section{Conclusions}

Even though ANSAs play a significant (albeit usually negative) role in international relations, their status under international law is quite vague. Despite the claims which are presented in the legal doctrine, ANSAs cannot form customary law understood as custom composed of two elements - practice and opinio juris - arising from the acts of ANSAs. Moreover, due to both the process of the formation of CIL, and the negative contribution the ANSAs would make, their acts cannot contribute to the formation of States' customary law. As a result, the proposal of a 'quasi-customary law of ANSAs', as created by or contributed by ANSAs, is only a doctrinal viewpoint, which is not justified by the actual position of ANSAs in international law.

\section{References}

Algerian National Liberation Front: Lettre du Comité de Libération de l'Afrique du Nord au Comité International de la Croix-Rouge, http://theirwords.org/media/transfer/ doc/sc_dz_fln_aln_1956_03-ad93ce79b5a926e49501e3d304a82b73.pdf, accessed 6 January 2019

ARAJÄRVI, Noora. The Changing Nature of Customary International Law: Methods of interpretation the concept of custom in international criminal tribunals. Abingdon: Routledge, 2014

Arend, Anthony Clark. Legal Rules and International Society. Oxford: Oxford University Press, 1999

58 Henckaerts, Jean-Marie, Doswald-Beck, Louise. Customary International Humanitarian Law. Volume 1: Rules. Cambridge: Cambridge University Press, 2005, p. xlii.

59 ILC (note 18) Draft Conclusion 4 [5], par. 3. 
Bos Marteen. The Identification of Custom in International Law. German Yearbook of International Law, 1982, no. 25

CASSESE, Antonio. International Law. Oxford: Oxford University Press, 2005

Chafin, Haley Elizabeth. Stolen Innocence: The United Nations' Battle against the Forced Recruitment and Use of Child Soldiers in Myanmar. Georgia Journal of International and Comparative Law, 2014, no. 43 (1)

CRAWFORD, James. Brownlie's Principles of Public International Law. Oxford: Oxford University Press, 2012

DOSWALD-BECK, Louise, HENCKAERTS, Jean-Marie. Customary International Humanitarian Law. Volume 1: Rules. Cambridge: Cambridge University Press, 2005

Eck, Kristine, Pettersson, Therese. Organized violence, 1989-2017. Journal of Peace Research, 2018, vol. 55, no. 4

Geneva Call: Mission, https://genevacall.org/who-we-are/, accessed 6 January 2019

Governance. Social Development. Humanitarian. Conflict. Applied Knowledge Services: International Legal Frameworks for Humanitarian Action. Topic Guide, https:// reliefweb.int/sites/reliefweb.int/files/resources/International\%20Legal\%20Frameworks\%20for\%20Humanitarian\%20Action.pdf, accessed 6 January 2019

Government of the Republic of the Philippines, NDFP: Comprehensive Agreement on Respect for Human Rights and International Humanitarian Law, http://theirwords. org/media/transfer/doc/ph_ndfp_1998_17-ef3249df335f48cd378d1c5082457be4. pdf, accessed 6 January 2019

Human Rights Watch: Syria. Events of 2016, https://www.hrw.org/world-report/2017/ country-chapters/Syria, accessed 6 January 2019

Institute for Economics and Peace: Global Peace Index 2017, http://visionofhumanity.org/ app/uploads/2017/06/GPI17-Report.pdf, accessed 6 January 2019

Karen National Union: Policy on Humanitarian Operation in Ceasefire Zone, http:// theirwords.org/media/transfer/doc/knu_policy_on_humanitarian_operation_2013f27bab81ffc78dc8d7b2592422b0a437.pdf, accessed 6 January 2019

Kopelmanas, Lazare. Custom as a Means of the Creation of International Law. British Year Book of International Law, 1937, no. 18

Letter to President by Rodrigo Londoño Echeverri, http://www.farc-ep.co/comunicado/ que-se-cumpla-lo-prometido-y-firmado-presidente-santos.html, accessed 6 January 2019

Liang, Jessica. Modifying the UN Charter through Subsequent Practice: Prospects for the Charter's Revitalisation. Nordic Journal of International Law, 2012, no. 81 (1)

MENDELSON, Maurice. The Formation of Customary International Law. Recueil de Cours, 1998, vol. 272

Mozambique National Resistance, Government of Mozambique: Joint Declaration on the Guiding Principles of Humanitarian Assistance, http://theirwords.org/media/ transfer/doc/mz_renamo_1992-734e52603d5bdd69f4761aad9247ecad.pdf, accessed 6 January 2019

National Democratic Front of the Philippines: Declaration and Program of Action for the Rights, Protection and Welfare of Children, http://theirwords.org/media/transfer/doc/1_ph_ndfp_2012_46-95b83d5994c9d675fa79541522e8c177.pdf, accessed 6 January 2019

OETER, Stefan. The Legitimacy of Customary International Law. In EGER, Thomas, OETER, Stefan, VOIGT, Stefan (eds). Economic Analysis of International Law. Contributions to the XIIIth Travemünde Symposium on the Economic Analysis of Law (March 
29-31, 2012). Tübingen: Mohr Siebeck, 2014

Postema, Gerald J. Custom in international law: a normative practice account. In Perreau - Saussine, Amanda, Murphy, James Bernard (eds) The nature of customary law: Legal, historical and philosophical perspectives. Cambridge: Cambridge University Press, 2007

Revolutionary United Front of Sierra Leone: The Eight Codes of Conduct, http://theirwords.org/media/transfer/doc/sl_ruf_01-1678c63ea48fb4e15f0f50c7c53ef15b.pdf, accessed 6 January 2019

Roberts, Anthea, Sivakumaran, Sandesh. Lawmaking by Nonstate Actors: Engaging Armed Groups in the Creation of International Humanitarian Law. Yale Journal of International Law, 2012, no. 37 (1)

RYNGAERT, Cedric. Non-State Actors and International Humanitarian Law. Working Paper, 2008, p. 6. Available at: <https://www.law.kuleuven.be/iir/nl/onderzoek/wp/ WP146e.pdf>

Sassòli, Marco. Transnational Armed Groups and International Humanitarian Law. Program on Humanitarian Policy and Conflict Research Harvard University Occasional Paper Series, 2006, no. 6

Sivakumaran, Sandesh. Binding Armed Opposition Groups. International and Comparative Law Quarterly, 2006, vol. 55

SPLM/A-N: Resolution No. (6)-2013, http://theirwords.org/media/transfer/doc/splm_n_ human_rights_court_en_1-c19ad16282af42e9765a1ce3569950bd.pdf, accessed 6 January 2019

The Free Syrian Army: Declaration, http://theirwords.org/media/transfer/doc/fsa declaration_2016-1078a35c56fc236e94abb00ac3911717.pdf, accessed 6 January 2019

THIRLWAY, Hugh. The Sources of International Law. Oxford: Oxford University Press, 2014

United States Institute for Peace: Humanitarian Cease Fire Agreement on the Conflict in Darfur, http://theirwords.org/media/transfer/doc/1_sd_slm_sla_jem_2004_33d3bacd2ca5696d09881a15de522cf21a.pdf, accessed 6 January 2019

United States Institute of Peace: Agreement on human rights, https://www.usip.org/sites/ default/files/file/resources/collections/peace_agreements/pa_es_07261990_hr.pdf, accessed 6 January 2019

Uppsala Conflict Data Program: Number of Conflicts 1975-2017, http://ucdp.uu.se/\#/, accessed 6 January 2019, accessed 6 January 2019

Uppsala Conflict Data Program: Year 2017, http://ucdp.uu.se/\#/year/2017, accessed 6 January 2019

van Steenberghe, Raphaël. Non-state actors from the perspective of the International Committee of the Red Cross. In d'Aspremont Jean (ed). Participants in the International Legal System. Multiple perspective on non-state actors in international law. Abingdon: Routledge, 2013

WOLFKE, Karol. Custom in present international law. Dordrecht: Springer, 1993 